\title{
Physiological Factors Affecting Response of Mature 'Valencia' Orange Fruit to CMN-Pyrazole. I. Effects of Young Fruit, Shoot, and Root Growth
}

\author{
Rongcai Yuan, Ulrich Hartmond, Angela Grant, and Walter J. Kender ${ }^{1}$ \\ University of Florida, Institute for Food and Agricultural Sciences, Citrus Research and Education \\ Center, 700 Experiment Station Road, Lake Alfred FL 33850-2299
}

Additional Index words. Citrus sinensis, ethylene, fruit abscission, fruit color, fruit detachment force

\begin{abstract}
Influence of young fruit, shoot, and root growth on response of mature 'Valencia' oranges [Citrus sinensis (L.) Osbeck] to the abscission chemical CMN-pyrazole was examined in 1999 and 2000 . CMN-pyrazole dramatically increased ethylene production in mature fruit and reduced the fruit detachment force (FDF), except during a period of reduced response to CMN-pyrazole in early May when spring vegetative growth, young fruit of the following year's crop, and mature fruit were all on the trees. Removal of spring flushes, which included spring vegetative shoots and leafy and leafless inflorescences, prevented any young fruit and shoot growth, but did not inhibit root growth. However, trunk girdling in combination with removal of spring flushes not only prevented growth of young fruit and shoots but also inhibited root growth. During the responsive period, there were no differences in either ethylene production or FDF of CMN-pyrazole-treated mature oranges between 1) the nonmanipulated trees and those manipulated by either 2) removal of spring flushes alone, or 3) in combination with trunk girdling. However, during the less responsive period, ethylene production in $\mathrm{CMN}$-pyrazole-treated mature oranges was significantly lower while the FDF was higher in nonmanipulated trees than in trees treated by either removal of spring flushes alone, or in combination with trunk girdling. There was no difference in either fruit ethylene production or FDF between trees manipulated by (2) removal of spring flushes alone, and (3) removal of spring flushes in combination with trunk girdling regardless of CMN-pyrazole application. Shoot growth terminated at least 2 weeks before the onset of the less responsive period. Removal of young fruit increased response of mature fruit to $\mathrm{CMN}$-pyrazole during the less responsive period. This suggests that hormones from rapidly growing young fruit may be responsible for the occurrence of the less responsive period. Chemical name used: 5-chloro3-methyl-4-nitro-1H-pyrazole (CMN-pyrazole).
\end{abstract}

Orange (Citrus sinensis) fruit have a very high detachment force at harvest (Brown, 1998). Successful mechanical harvesting of orange fruit is enhanced by use of abscission chemicals that reduce fruit detachment force (FDF). Early and midseason oranges usually mature in November or December, and appear to respond readily to the effective abscission chemicals. However, for the widely grown, late season, processing cultivar Valencia, the harvest season begins in early April ( $\approx 1$ year after full bloom) and extends through June. Spring vegetative growth, young developing fruit of the following year's crop, and mature fruit are all on the trees during most of the 'Valencia' harvest season. The response of mature fruit to abscission chemicals seems to be inconsistent (Cooper and Wilson, 1971; Hartmond et al., 2000a; Holm and Wilson, 1977; Wheaton et al., 1977). Mature 'Valencia' fruit respond poorly to abscission chemicals starting from late April or early May, and lasting for about 2 to 6 weeks (Hartmond et al., 2000a; Holm and Wilson, 1976; Wheaton et al., 1977). This condition is referred to as the less responsive period (Hartmond et al., 2000a). Normal response of mature 'Valencia' to abscission chemicals resumes following this period. The factors responsible for the less responsive period are unclear.

Hormones have been implicated in immature or mature fruit abscission. Young leaves and fruit are rich sources of auxin, gibberellins (GAs), and cytokinins (CTKs) (Davies, 1995). Based on these facts, it has been speculated that reduced responsiveness

Received for publication 25 Sept. 2000. Accepted for publication 9 Apr. 2001 Florida Agricultural Experiment Station journal series R-07797. We gratefully acknowledge financial support of the Florida Department of Citrus and assistance of L. Pozo. The cost of publishing this paper was defrayed in part by the payment of page charges. Under postal regulations, this paper therefore must be hereby marked advertisement solely to indicate this fact.

${ }^{1}$ Corresponding author; e-mail kender@lal.ufl.edu. of mature fruit to abscission chemicals is associated with the regreening of the fruit peel that may occur in May and June (Jahn and Young, 1976; Wheaton et al., 1977), and is caused by endogenous hormones such as GAs moving from young leaves of the spring flush (Holm and Wilson, 1976; Rasmussen, 1973) or auxin moving from young developing fruitlets to mature fruit (Wheaton et al., 1977). Roots also synthesize endogenous hormones such as CTKs and abscisic acid (Davies, 1995), and root growth of 'Valencia' orange is very active in spring (Bevington and Castle, 1985; Elezaby, 1989; Menocal-Barberena, 1999). Previous reports showed that root growth was inhibited by trunk girdling performed before bloom in litchi (Litchi chinensis Sonn.) trees (Yuan and Huang, 1993).

The abscission chemical CMN-pyrazole is the only known chemical that has the ability to loosen mature 'Valencia' orange fruit without causing injury to bloom, young fruit, or foliage (Holm and Wilson, 1977; Kender, 1998; Wilson, 1973). Therefore, the goal of our investigation was to study the influence of young fruit, shoot, and root growth on response of mature 'Valencia' orange fruit to the abscission chemical CMN-pyrazole.

\section{Materials and Methods}

All field experiments were conducted with 10-year-old (1999) or 11-year-old (2000) 'Valencia' orange trees grafted on rough lemon (Citrus jambhiri Lush) rootstock located at the Citrus Research and Education Center, Lake Alfred, Fla. in the 1999 and 2000 harvest seasons. Full bloom occurred approximately in late March in Lake Alfred, Fla. All experiments were arranged in a randomized complete block design.

TIME COURSE FOR THE RESPONSE OF MATURE FRUIT TO CMNPYRAZOLE (EXPT. 1). Two groups of 180 uniform mature fruit were 
selected and marked on each of four trees. Each tree was a block. One group of marked fruit in each tree was sprayed on 29 Mar. 1999 with a solution of CMN-pyrazole at $150 \mathrm{mg} \cdot \mathrm{L}^{-1}$ containing $0.125 \%$ of the adjuvant Kinetic (Setre Chem. Co., Memphis, Tenn.) using a pressurized hand sprayer. The other group of fruit in each tree was sprayed only with $0.125 \%$ Kinetic and served as a control. Ethylene production of five fruit from each group on each of four trees was determined $0,1,2,3,4$, and $7 \mathrm{~d}$ after application of CMN-pyrazole as described in Hartmond et al. (2000b). Briefly, internal air was evacuated by vacuum from fruit submerged in degassed water and collected. Ethylene concentration was measured with a gas chromatograph (Hewlett-Packard, Avondale, Pa.) equipped with an alumina column and flame ionization detector. FDF was measured at the same time using a digital force gauge (Force Five, Wagner Instruments, Greenwich, Conn.) (Hartmond et al., 2000a).

SEASONAL VARIATION IN THE RESPONSE OF MATURE FRUIT TO CMNPYRAZOLE IN 1999 (EXPT. 2). Starting on 9 Mar. 1999 and ending on 2 June 1999, two groups of 20 uniform mature fruit were selected and marked on each of four trees on each date at 7 to 10 dintervals. Each tree was a block. One group of marked fruit in each tree was

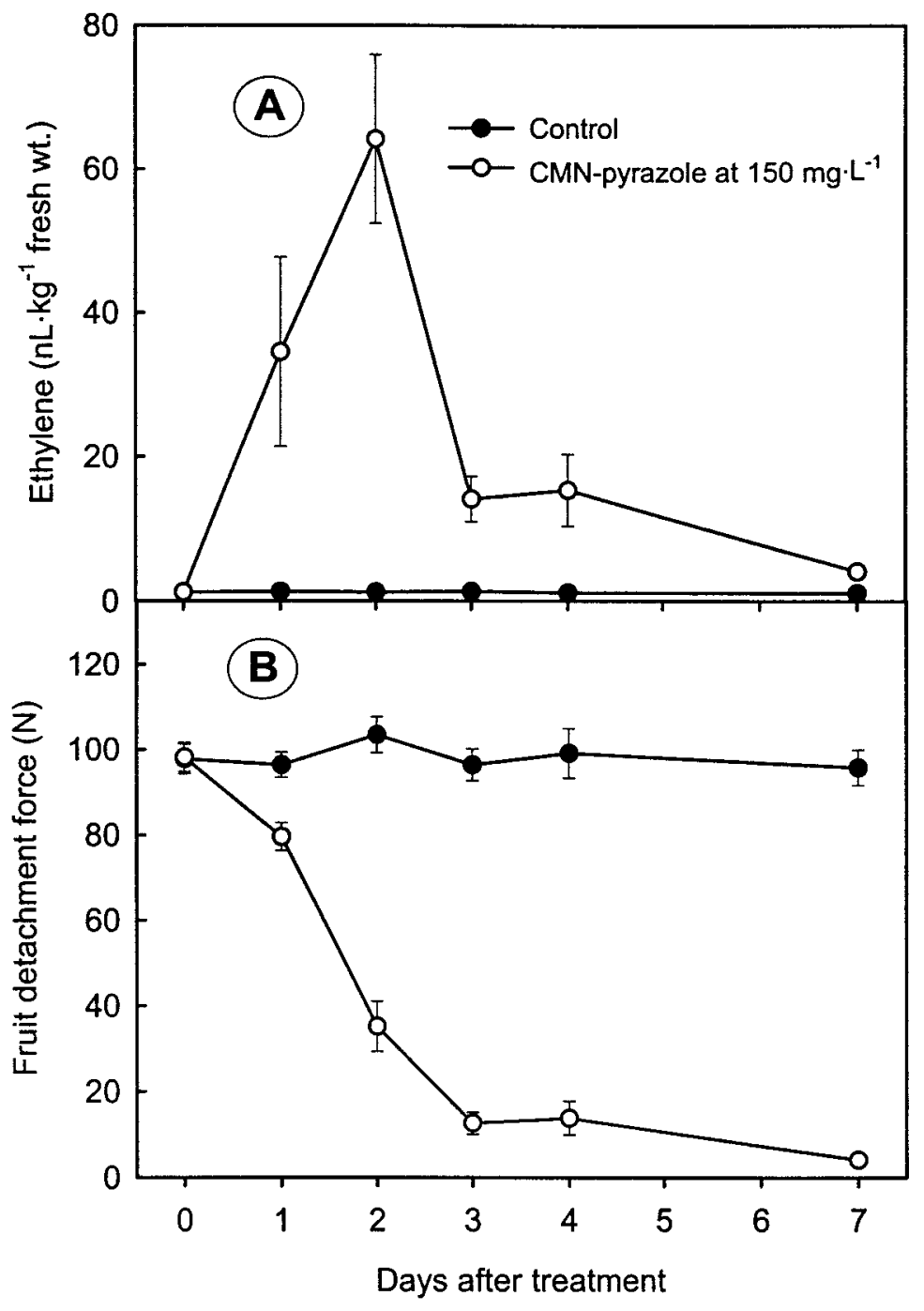

Fig. 1. Effects of CMN-pyrazole at $150 \mathrm{mg} \cdot \mathrm{L}^{-1}$ on $(\mathbf{A})$ fruit ethylene production and $(\mathbf{B})$ fruit detachment force of 'Valencia' oranges. Treatments were applied 29 Mar. 1999. Data are means \pm SE $(n=80)$. sprayed with a solution of CMN-pyrazole at $150 \mathrm{mg} \cdot \mathrm{L}^{-1}$ containing $0.125 \%$ of the adjuvant Kinetic using a pressurized hand sprayer. The other group of fruit in each tree was sprayed only with $0.125 \%$ Kinetic and served as a control. A total of 11 spray treatments were applied during the harvest season. FDF was measured $7 \mathrm{~d}$ after each spray application as described previously. Ethylene production of five fruit from each group on each of four trees was determined $2 \mathrm{~d}$ after application of $\mathrm{CMN}-$ pyrazole as described in Expt. 1.

Fruit maturity was measured at 1 to 2 week intervals from 13 Jan. to 16 June 1999 using standard juice analysis procedures for soluble solids and titratable acids (Wardowski et al., 1991).

EFFECTS OF REMOVAL OF FLUSHES AND TRUNK GIRDLING ON THE RESPONSE OF MATURE FRUIT TO CMN-PYRAZOLE (EXPT. 3). Twelve uniform trees were selected and grouped into four blocks of three trees each. One tree in each block was manipulated by either 1) removing flushes alone, or 2) in combination with trunk girdling. The third tree in each block was not manipulated and served as a control. The flushes that were removed included spring vegetative shoots, and leafy and leafless inflorescences. All new shoots, leafy and leafless inflorescences were removed from the beginning of spring growth until mid-June 1999. Therefore, no young fruit and new shoots were found on the trees whose flushes were removed. Trunks were girdled on 16 Feb. 1999 by removing a 7-mm-wide strip of bark including phloem and cambial tissue. The girdle was monitored periodically for cambial growth and was scraped to prevent phloem reconnection until mid-June. Each block was a replication.

A $30 \times 60 \times 60 \mathrm{~cm}$ root observation chamber was constructed and buried beneath the canopy at the dripline $\approx 120 \mathrm{~cm}$ from the trunk with a root observation window of $26 \times 53 \mathrm{~cm}$ width facing the trunk of each of nine trees. The gap in front of the root observation window was filled with sieved soil to obtain good contact and allow regrowth of roots. The main frame of the chambers was constructed from $2 \times 3.5 \mathrm{~cm}$ timbers, the observation window of the chambers was made from 3-mm-thick clear polycarbonate sheets, and the other sides of the chambers were made of 1mm-thick transparent polyvinyl chloride plastic sheets. The chambers were covered with an insulated board to exclude light and limit temperature changes. Root growth was traced on the observation window with a marker and measured weekly. Twenty young fruit on each tree were tagged and measured weekly for diameter. Four branches of $\approx 5$ to $6 \mathrm{~mm}$ in diameter from each tree were tagged and their shoot growth was measured weekly.

Two groups of 20 uniform mature fruit were selected and marked on each of the 12 manipulated and nonmanipulated trees on 9 Mar., 4 May, 11 May, 18 May, and 25 May 1999, respectively. One group from each tree was sprayed with a solution of CMN-pyrazole at 0 or $150 \mathrm{mg} \cdot \mathrm{L}^{-1}$ containing $0.125 \%$ of Kinetic using a pressurized hand sprayer. FDF was measured $7 \mathrm{~d}$ after spraying, and ethylene production of 5 fruit from each group on each of four trees was determined $2 \mathrm{~d}$ after application of $\mathrm{CMN}$-pyrazole as described previously.

SEasonal VARIATION IN THE RESPONSE OF MatURe FRUIT TO CMN-PYRAZOLE IN 2000 (EXPT. 4). Seasonal variation in the response of mature 'Valencia' orange fruit to CMN-pyrazole was determined again in 2000. Starting on 29 Mar. 2000 and ending on 2 June 2000, two groups of 20 uniform mature fruit were selected and marked on each of four trees on each date at 7 
to 10 d intervals. Each tree was a block. One group of marked fruit in each tree was sprayed with a solution of CMN-pyrazole at 100 $\mathrm{mg} \cdot \mathrm{L}^{-1}$ containing $0.125 \%$ Kinetic using a pressurized hand sprayer. The other group of fruit in each tree was sprayed only with $0.125 \%$ Kinetic and served as a control. A total of eight spray treatments were applied during the harvest season. FDF was measured $7 \mathrm{~d}$ after treatment as described in Expt. 1. In addition, 10 young fruit on each of four trees were tagged and measured weekly for diameter.

EFFECTS OF YOUNG FRUIT ON EFFICACY OF CMNPYRAZOLE (EXPT. 5). Six mature trees were selected and grouped into three blocks. Flowers and young fruit on one tree from each block were completely removed on 30 Mar. 2000. The new vegetative shoots or leaves were not removed. Another tree from each block was not manipulated and served as a control. Two groups of 20 uniform mature fruit from each tree were selected and marked. One group of 20 mature fruit in each tree received a spray of $\mathrm{CMN}$-pyrazole on 5 May 2000 at 0 or $100 \mathrm{mg} \cdot \mathrm{L}^{-1}$ containing $0.125 \%$ of the adjuvant Kinetic. FDF was measured $7 \mathrm{~d}$ after treatment. Additional samples of 10 mature fruit from each tree were harvested, washed, dried with paper towels, and used to determine fruit color on 29 Mar., 3 May, 23 May, and 8 June 2000, respectively. Peel color (chroma and hue angle) at the top of mature fruit around the stem and abscission zone was measured at three positions along the shoulder of each fruit using a chroma meter (CR200; Minolta Co., Asaka, Japan) measuring in CIE 1976 (L*, a*, b*) (McGuire, 1992) $[\mathrm{CIE}=$ Commission Internationale de l'Eclairage (International Commission on Illumination)]. Chroma $\left(C^{*}\right)$, calculated as $\left(a^{* 2}+b^{* 2}\right)^{1 / 2}$, is an index of color saturation or intensity (degree of departure from gray toward pure chromatic color). Hue angle $\left(\mathrm{h}^{\circ}\right)\left(0^{\circ}=\right.$ red-purple, $90^{\circ}=$ yellow, $180^{\circ}=$ bluish green, $270^{\circ}=$ blue) is calculated from the arctangent of $a^{*} / b^{*}$.

Statistical analyses. Statistical analyses included analysis of variance, Duncan's multiple range test, orthogonal polynomial comparison, and regression. When interactions of main effects were significant, sums of squares were partitioned into sums of squares of one main effect nested within each level of the other main effect involved in the interaction. Statistical Analysis Systems Software for PC (SAS Institute Inc., Cary, N.C.) was used for all data analyses.

\section{Results}

TIME COURSE FOR THE RESPONSE OF MATURE FRUIT TO CMN-PYRAZOLE (EXPT. 1). Applications of CMNpyrazole at $150 \mathrm{mg} \cdot \mathrm{L}^{-1}$ to 'Valencia' orange fruit dramatically increased fruit ethylene production (Fig. 1A). Ethylene production peaked $2 \mathrm{~d}$ after application of CMN-pyrazole. Applications of CMN-pyrazole at $150 \mathrm{mg} \cdot \mathrm{L}^{-1}$ also effectively reduced FDF which decreased from $\approx 100$ to $13 \mathrm{~N}, 3 \mathrm{~d}$ following application (Fig. 1B).

SEASONAL VARIATION IN THE RESPONSE OF MATURE FRUIT TO CMNPYRAZOLE IN 1999 (EXPT. 2). Mature 'Valencia' orange fruit responded variably to $\mathrm{CMN}$-pyrazole over the 3-month observation period (Fig. 2A and B). Compared with the nontreated control, FDF of treated fruit was extremely low and fruit ethylene production was extremely high before 27 Apr. CMN-pyrazole then became less effective in reducing FDF of mature fruit and increasing fruit ethylene production. After $25 \mathrm{May}$, FDF of treated fruit decreased and fruit ethylene production increased again. Soluble solids concentration to acid ratio of nontreated fruit increased from
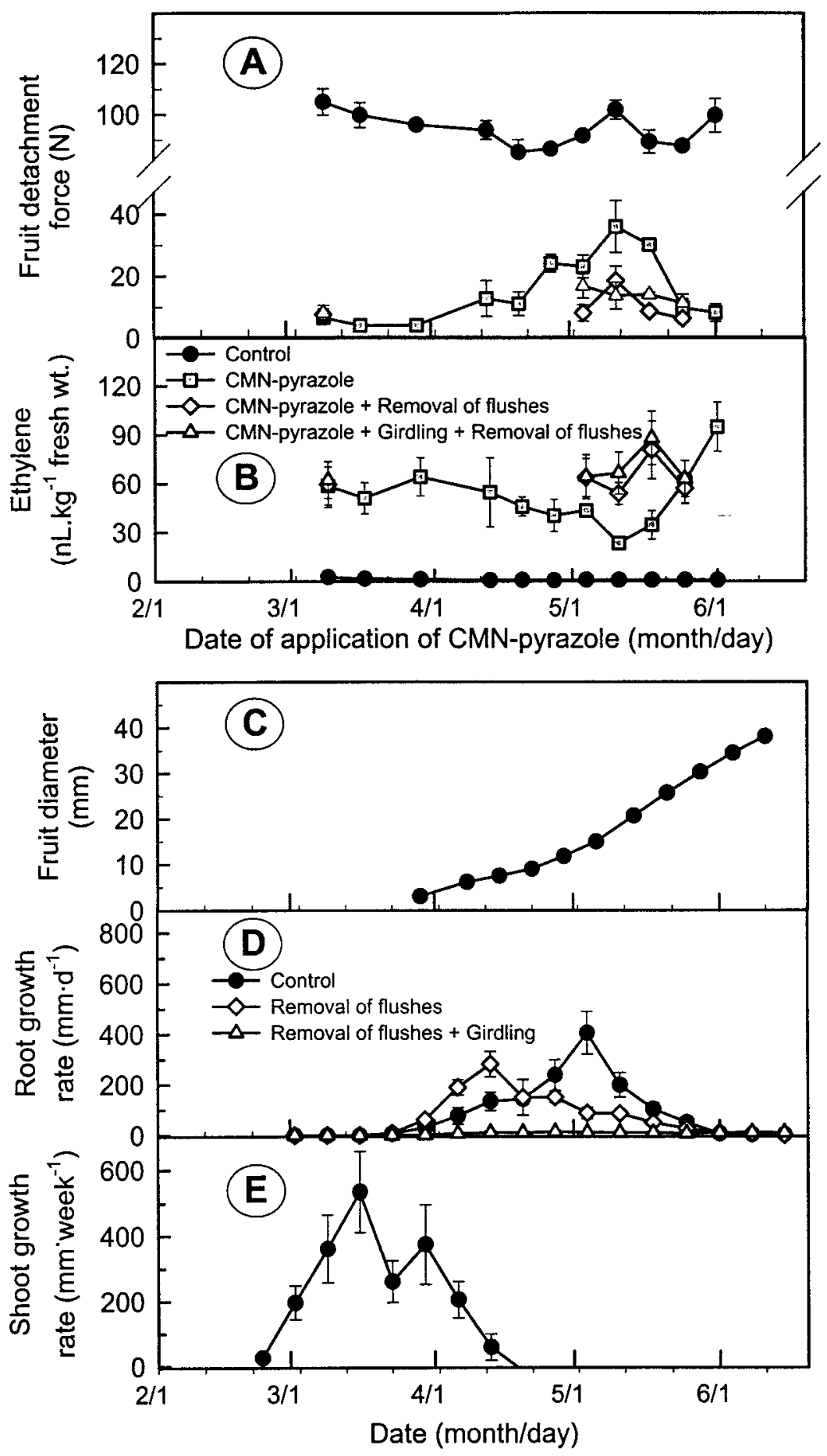

Fig. 2. Effects of CMN-pyrazole at $150 \mathrm{mg} \cdot \mathrm{L}^{-1}$, removal of flushes, and trunk girdling on (A) FDF and (B) ethylene production of mature fruit, and on growth of $(\mathbf{C})$ young fruit, (D) roots, and (E) shoots in 'Valencia' oranges. FDF and ethylene production were measured 7 and $2 \mathrm{~d}$ after application of CMNpyrazole, respectively. Trunk girdling and removal of flushes were applied on 16 Feb. 1999. Data are means \pm SE $(n=80$ in A, 20 in B, and 3 in C, D, and E, respectively). 


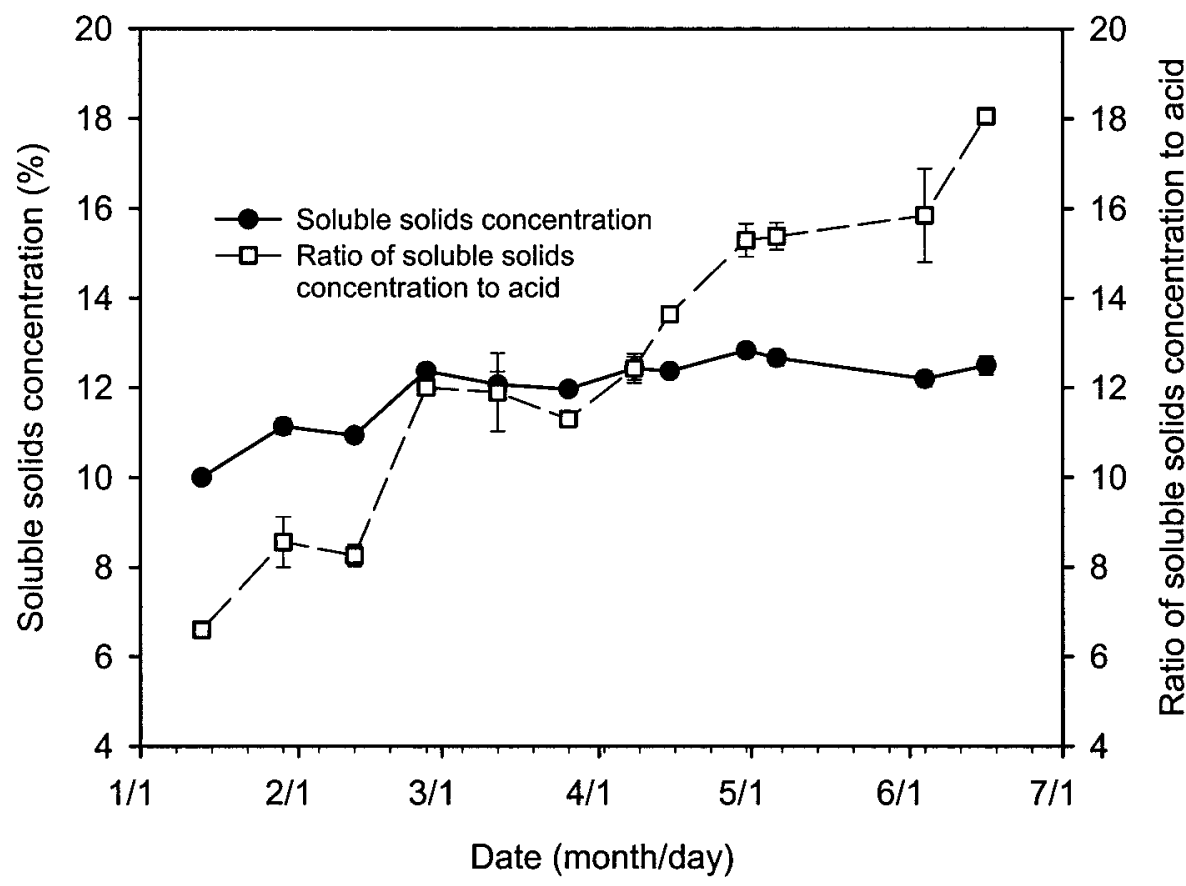

Fig. 3. Seasonal fluctuation in soluble solids concentration, and ratio of soluble solids concentration to \% acid of nontreated mature 'Valencia' oranges in Lake Alfred, Fla., 1999. Data are means \pm SE $(n=3)$.

$\approx 6.6$ in mid-January to 18 in mid-June (Fig. 3).

EFFECTS OF REMOVAL OF FLUSHES AND TRUNK GIRDLING ON THE RESPONSE OF MATURE FRUIT TO CMN-PYRAZOLE (EXPT. 3). Nonmanipulated control trees bloomed in late March. The young fruit were $\approx 10 \mathrm{~mm}$ in diameter at the beginning of the less responsive period (27 Apr.). Due to removal of all flowers, no young fruit were found on the trees manipulated by either removing flushes alone or in combination with trunk girdling (Fig. 2C). Root growth of nonmanipulated control trees began immediately after full bloom in late March, peaked in early May, and terminated in late May (Fig. 2D). Root growth on trees with only the flush removed started at the same time as the nonmanipulated control trees, but reached its maximum earlier. Trunk girdling in combination with removal of flushes inhibited root growth. There were two waves of spring shoot growth on nonmanipulated control trees over the 4-month observation period (Fig. 2E). Shoot growth on nonmanipulated control trees stopped in mid April, whereas no shoot growth was recorded on the trees manipulated by either removing flushes alone or in combination with trunk girdling.

Overall, application of CMN-pyrazole at $150 \mathrm{mg} \cdot \mathrm{L}^{-1}$ reduced FDF of mature fruit and increased fruit ethylene production(Fig. 2A and B). Without application of CMN-pyrazole, there was no significant difference in FDF and fruit ethylene production between manipulated and nonmanipulated trees (data not presented). With application of CMN-pyrazole, the mature fruit on nonmanipulated trees had higher FDF and lower ethylene production than those on trees manipulated by flush removal alone or in combination with trunk girdling on 4,11 , and 18 May (during the less responsive period), but not on 9 Mar. (before the less responsive period), and 25 May (after the less responsive period).

Fig. 4. Seasonal variation in (A)FDF of mature fruit in response to CMN-pyrazole at $100 \mathrm{mg} \cdot \mathrm{L}^{-1}$, and (B) young fruit growth in 'Valencia' oranges in 2000 . FDF was measured $7 \mathrm{~d}$ after treatment. Data are means \pm SE $(n=80$ in $A$, and 40 in B, respectively). Full bloom was late Mar. 1999 for mature fruit, and late Mar. 2000 for young fruit.
SEASONAL VARIATION IN THE RESPONSE OF MATURE FRUIT TO CMN-PYRAZOLE IN 2000 (EXPT. 4). FDF of CMN-pyrazole-treated mature fruit was extremely low in March and early April, increased dramatically after 25 Apr., and decreased again after 2 June (Fig. 4A). Overall, control fruit had uniformly higher FDF than CMN-pyrazole-treated fruit throughout the period from March to June.

EFFECTS OF YOUNG FRUIT ON EFFICACY OF CMN-PYRAZOLE(EXPT.5). Nonmanipulated control trees bloomed in late March. At the beginning of the less responsive period the size of young fruit was $\approx 10 \mathrm{~mm}$ in diameter (Fig. 4B). There were no young fruit on trees with flowers and young fruit removed.

There was a significant interaction between application of $\mathrm{CMN}$-pyrazole during the less responsive period and removal of flowers and young fruit (Fig. 5). Without application of CMN-pyrazole, the FDF of mature fruit on nonmanipulated control trees was similar to that of trees with flowers and young fruit removed. Trees with flowers and young fruit removed

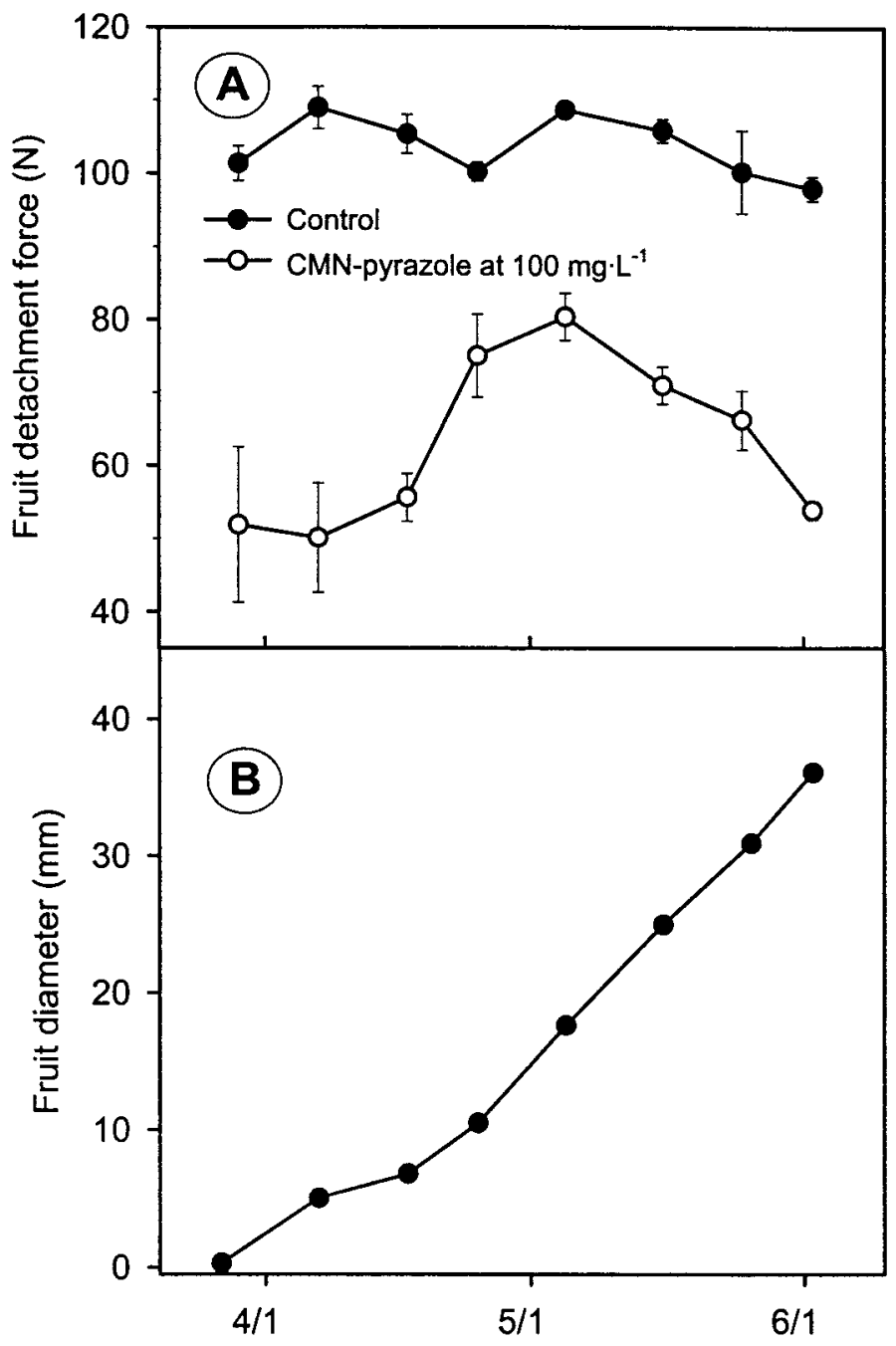

Date (month/day) 


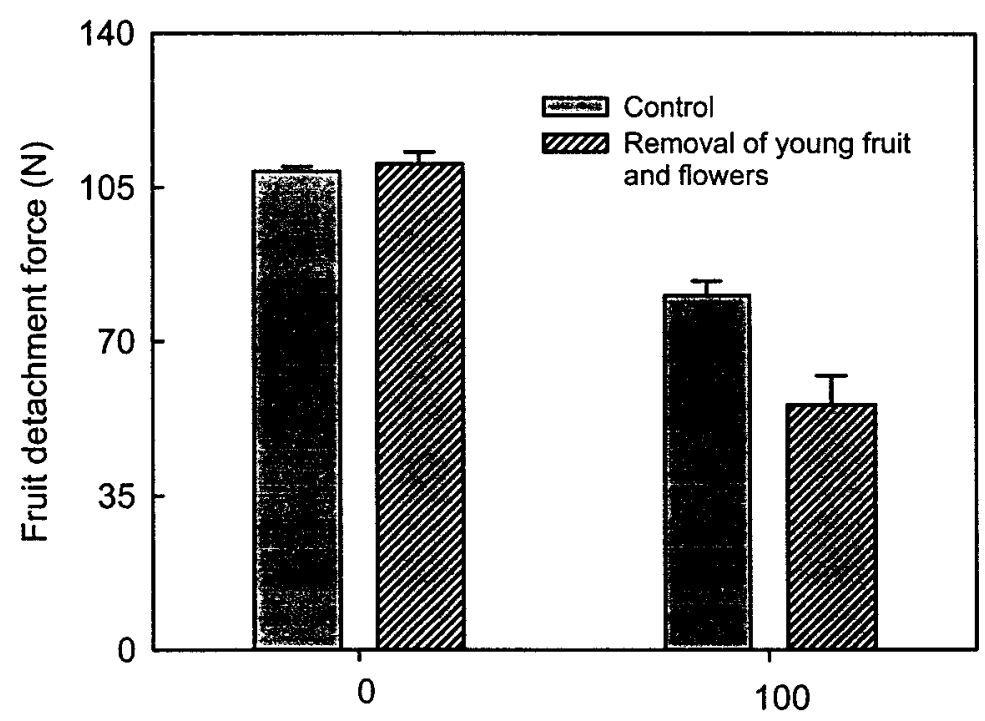

CMN-pyrazole $\left(\mathrm{mg}^{-\mathrm{L}^{-1}}\right)$

Fig. 5. Effects of young fruit and CMN-pyrazole at $100 \mathrm{mg} \cdot \mathrm{L}^{-1}$ applied on 5 May ( $\approx 13$ months after full bloom for mature fruit) on FDF of mature 'Valencia' oranges in 2000. FDF was measured $7 \mathrm{~d}$ after treatment. Data are means $\pm \mathrm{SE}$ (n $=60$ ). Full bloom was late Mar. 2000 for young fruit. Young fruit or flowers were removed on 30 Mar. 2000.

had lower FDF than nonmanipulated control trees with application of CMN-pyrazole at $100 \mathrm{mg} \cdot \mathrm{L}^{-1}$ on 5 May $(\approx 13$ months after full bloom for mature fruit).

Chroma $\left(\mathrm{C}^{*}\right)$ of mature fruit decreased (Fig. 6A), and mature fruit became more green-yellow with time regardless of manipulation of trees (Fig. 6B). The mature fruit from trees with young fruit removed were more green-yellow than those from trees with young fruit after 23 May.

\section{Discussion}

Response of mature 'Valencia' orange fruit to the abscission chemical CMN-pyrazole was variable in our investigations (Figs. 2A and $B$ and $4 A$ ). FDF of treated mature fruit decreased dramatically when CMN-pyrazole was applied before late April (about 13 months after full bloom). After this time, the decrease in FDF of treated mature fruit became less pronounced. This less responsive period was sustained for 4 to 5 weeks. The abscission chemical became effective again after late May or early June. Our results are in agreement with previous reports demonstrating a period of less responsiveness of mature 'Valencia' orange fruit to abscission chemicals, such as CMN-pyrazole and (2chloroethyl) phosphonic acid (ethephon), in early May (Cooper and Wilson, 1971; Hartmond et al., 2000a; Wheaton etal., 1977).

It has been speculated that the less responsive period is caused by changes in endogenous hormones resulting from active spring vegetative growth (Holm and Wilson, 1976; Rasmussen, 1973) or young fruit growth (Wheaton et al., 1977). Our results in 1999 showed that a less responsive period did not occur in the trees manipulated by removal of new vegetative shoots, flowers, and young fruit alone, or in combination with trunk girdling, which additionally inhibited root growth (Fig. 2). New spring shoot growth completely terminated on nonmanipulated control trees at the onset of the less responsive period (Fig. 2E). Young fruit removal increased response of mature fruit to application of $\mathrm{CMN}$-pyrazole during the less responsive period (Fig. 5). These results suggest that young fruit, not vegetative shoots or roots, may be the primary factor responsible for the occurrence of the less responsive period.

Chemically induced abscission of mature fruit involves ethylene production. Abscission chemicals promote mature fruit abscission by releasing ethylene directly, or by stimulating wound ethylene production through injury of fruit tissue (Wheaton et al., 1977; Wilson, 1973). Wheaton et al. (1977) and Wilson (1973) attribute promotion of wound ethylene production to injury of fruit tissue, especially peel, as the mode of action of CMN-pyrazole as an abscission chemical for oranges. In our studies, fruit ethylene production of $\mathrm{CMN}$-pyrazole-treated mature fruit was strikingly lower during the less responsive period than during the responsive period (Fig.

Fig. 6. Effects of young fruit on the fruit color $\left[(\mathbf{A}) \mathrm{C}^{*}\right.$ and $\left.(\mathbf{B}) \mathrm{h}^{\circ}\right]$ of mature 'Valencia' oranges in the 2000 season. Data are means $\pm \mathrm{SE}(\mathrm{n}=30)$. $\mathrm{C}^{*}=$ chroma (degree of departure from gray toward pure chromatic color). $\mathrm{h}^{\circ}=$ hue angle $\left(\mathrm{h}^{\circ}\right)\left(0^{\circ}=\right.$ red-purple, $90^{\circ}=$ yellow, $180^{\circ}=$ bluish green, and $270^{\circ}=$ blue $)$

${ }^{* * * *}$ Significant at $P<0.001$.

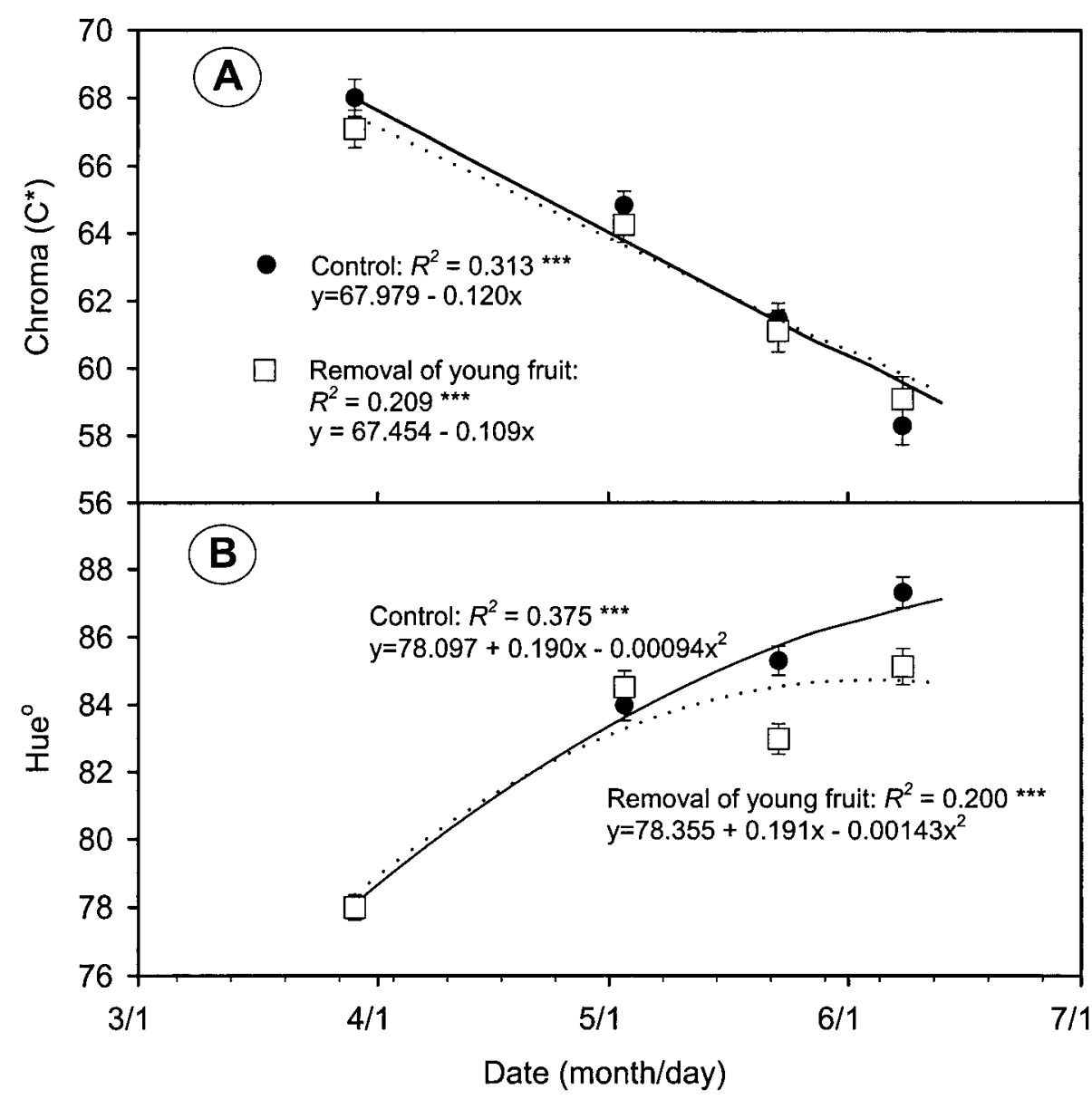


2B). However, CMN-pyrazole-induced ethylene production of fruit on trees manipulated by removal of flushes alone or in combination with trunk girdling remained high during the less responsive period (Fig. 2B). Young fruit are rich sources of endogenous plant hormones, such as auxin, GAs, and CTKs (Garcia-Papa and Garcia-Martinez, 1984; Goldschmidt, 1976; Hofman, 1990). Therefore, it is reasonable to assume that the hormones resulting from young growing fruit could change sensitivity of mature orange fruit to $\mathrm{CMN}$-pyrazole. Further experiments that measure quantities of endogenous hormones should be conducted to determine which hormones are primarily associated with the less responsive period. Such information would be important for designing practical growth regulator treatments to loosen oranges for mechanical harvesting. Proper management of abscission chemical application during the less responsive period will be required by the grower to overcome the lack of response. Higher doses of abscission chemicals may be needed at that time.

Some reports have suggested that the phenomena of less responsiveness and regreening of mature 'Valencia' orange fruit are closely related and result from changes of endogenous hormones (Holm and Wilson, 1976, 1977; Rasmussen, 1973). Others indicate that these two phenomena are independent (Wheaton et al., 1977). In our studies, external color of mature 'Valencia' orange fruit became more green-yellow over time regardless of the presence of young fruit on the tree (Fig. 6B). The mature fruit from nonmanipulated control trees were more green-yellow than those from trees with young fruit removed only after late May when the less responsive period was over. These results suggest that regreening and the less responsive period may be distinctly separate events.

\section{Literature Cited}

Bevington, K.B. and W.S. Castle. 1985. Annual root growth pattern of young citrus trees in relation to shoot growth, soil temperature, and soil water content. J. Amer. Soc. Hort. Sci. 110:840-845.

Brown, G. 1998. Florida citrus can be mechanically harvested. Amer. Soc. Agr. Eng. Annu. Intl. Mtg., 12-16 July 1998, Orlando, Fla. Paper 981091.

Cooper, W.C. and W.C. Wilson. 1971. Abscission chemicals in relation to the harvest of 'Valencia' oranges. Proc. Fla. State Hort. Soc. 84:7076.

Davies, P.J. 1995. The plant hormones: Their nature, occurrence, and functions, p. 1-12. In: P.J. Davies (ed.). Plant hormones. Kluwer Academic Publ., 3300 AA Dordrecht, The Netherlands.
Elezaby, A.A. 1989. Physiological and biological studies on root systems of some citrus stocks. PhD diss. Cairo Univ., Cairo, Egypt.

Garcia-Papa, M.A. and J.L. Garcia-Martinez. 1984. Endogenous plant growth substances content in young fruits of seeded and seedless Clementine mandarin as related to fruit set and development. Scientia Hort. 22:265-274.

Goldschmidt, E.E. 1976. Endogenous growth substances of citrus tissue. HortScience 11:95-99.

Hartmond, U., J.D. Whitney, J.K. Burns, and W.J. Kender. 2000a. Seasonal variation in the response of 'Valencia' orange to two abscission compounds. HortScience 35:226-229.

Hartmond, U., R. Yuan, J.K. Burns, A. Grant, and W.J. Kender. 2000b. Citrus fruit abscission induced by methyl-jasmonate. J. Amer. Soc. Hort. Sci. 125:547-552.

Hofman, P.J. 1990. Abscisic acid and gibberellins in the fruitlets and leaves of 'Valencia' orange in relation to fruit growth and retention. Scientia Hort. 42:257-267.

Holm, R.E. and W.C. Wilson. 1976. Loss in the capacity of 'Valencia' oranges treated with abscission chemicals to produce ethylene and fruit loosening during the regreening period. Proc. Fla. State Hort. Soc. 89:35-38.

Holm, R.E. and W.C. Wilson. 1977. Ethylene and fruit loosening from combinations of citrus abscission chemicals. J. Amer. Soc. Hort. Sci. 102:576-579.

Jahn, O.L. and R. Young. 1976. Changes in chlorophyll a, b, and a/b ratio during color development in citrus fruit. J. Amer. Soc. Hort. Sci. 101:416-418.

Kender, W.J. 1998. The Florida experience with citrus abscission chemicals, p. 52-57. In: W.J. Kender and J.K. Burns (eds.). Proc. Citrus Abscission Workshop, 3-4 Feb. 1998, Citrus Res. and Edu. Ctr., Lake Alfred, Fla.

McGuire, R.G. 1992. Reporting of objective color measurements. HortScience 27:1254-1255.

Menocal-Barberena, O.A. 1999. Citrus fibrous root distribution as affected by rootstock and irrigation rates of reclaimed water. MS thesis, Univ. Florida., Gainesville.

Rasmussen, G.K. 1973. The effect of growth regulators on degreening and regreening of citrus fruit. Acta Hort. 34:473-478.

Wardowski, W., J. Soule, J. Whigham, and W. Grierson. 1991. Florida citrus quality test. Fla. Coop. Ext. Service Bul. SP 99.

Wheaton, T.A., W.C. Wilson, and R.E. Holm. 1977. Abscission response and color changes of 'Valencia' oranges. J. Amer. Soc. Hort. Sci. 102:580-583.

Wilson, W.C. 1973. A comparison of cycloheximide with a new abscission chemical. Proc. Fla. State Hort. Sci. 86:56-60.

Yuan, R. and H. Huang. 1993. Regulation of root and shoot growth and fruit drop of young litchi trees by trunk girdling in view of source-sink relationships. J. Fruit Sci. 10:195-198. 